\title{
A Model of Strategic Marketing Decision Premises
}

\author{
Linus Osuagwu ${ }^{1}$ \\ ${ }^{1}$ School of Business \& Entrepreneurship, American University of Nigeria, Nigeria \\ Correspondence: Linus Osuagwu, School of Business \& Entrepreneurship, American University of Nigeria, \\ Nigeria. E-mail: linus.osuagwu@aun.edu.ng
}

Received: April 7, 2016 Accepted: April 26, 2016 Online Published: May 24, 2016

doi:10.5539/ijms.v8n3p145 URL: http://dx.doi.org/10.5539/ijms.v8n3p145

\begin{abstract}
The paper utilized some relevant empirical and conceptual works in extant literature to sketch a model of the relations among marketing environment, strategic marketing decisions and effectiveness. The paper reveals that some forms of supports exist in extant literature regarding the impacts of marketing environment on strategic marketing decisions and effectiveness, and impacts of strategic marketing decisions on strategic marketing effectiveness. However, relevant extant literature seems to have ignored the impacts of strategic marketing decisions on marketing environment. Also, relevant extant literature contains some gaps regarding the impacts of strategic marketing effectiveness on marketing environment and strategic marketing decisions. The paper concludes that these important relationships in strategic marketing decisions, omitted in extant literature, should be incorporated for a more comprehensive understanding of the relevant issues in strategic management decisions. The paper proposes an empirical research agenda to test the model in some business functions, sectors, cultures, contexts or premises.
\end{abstract}

Keywords: decision premises, marketing effectiveness, marketing environment, marketing models, strategic marketing

\section{Introduction}

Business organizations, generally, are associated with many environments and these environments determine the decision alternatives available and the degree of achievement of organizational efficiency and effectiveness. According to Simon (1997), business organizations can be studied and understood with regard to how their decisions are influenced by the decision premises/environments (comprising relevant economical, legal, sociological and psychological factors) and how the decision premises are in turn influenced by organizational decisions in their quest to achieve organizational efficiency and effectiveness. Generally, organizational managers have always shown interest in relevant environments, strategic tendencies and performance, including connections among these three major issues. This holds true for all organizational business functions, including marketing, finance, human resource management and production management, among others.

Most organizational decisions, including marketing decisions, are complex and uncertain, and made under complex and uncertain environments or decision premises. Consequently, environmental conditions pose some forms of difficulty in determining the worth, efficiency and effectiveness of organizational decisions (Paramkusham, 2013). Kumar (2015) argues that the rapid changes in contemporary business environments place some burden on the marketing discipline to provide useful knowledge for academics and practitioners. Therefore, any marketing theory or research result which proves substantially that marketing practice is explained by existing marketing knowledge should be celebrated as an indication that marketing academics, researchers and scholars are making some progress (Meyer, 2015). According to Eisend (2015), Marketing is a successful academic discipline (Eisend, 2015).

Practical marketing is one of the organic business functions concerned with exchange transactions and relationships focused on achieving customer satisfaction and organizational efficiency and effectiveness. It consists of individual and organizational decisions or choices directed towards achieving marketing goals and objectives, in addition to adapting to the relevant environment or decision premises. Some of the major relevant decisions which a marketer can make relate to selecting a market segment of interest and designing and implementing relevant marketing strategies, among others. Decisions on these broad issues are a function of the relevant marketing environment (decision premises) and the goals and objectives to be achieved. Marketing 
decisions, which are sensitive to the environment, require commitment of substantial resources, and oriented towards long term goals and objectives are referred to as strategic marketing decisions.

This means, therefore, that the marketing decisions of an organization depend on the prevailing marketing environment and the goals/objectives achieved or to be achieved. However, it may be appropriate to reason that the marketing decisions of an organization determine the achievement and/or non-achievement of its marketing goals/objectives, in addition to affecting developments in the marketing environment. Therefore, there are relations among marketing environment, marketing decisions and marketing goals/objectives; each of these three major constructs may be seen as dependent or independent depending on the focus of analysis. The relations among these major marketing constructs can be modeled and tested using empirical data in specific marketing organizations, contexts, sectors and countries.

\section{Conceptualizations of Marketing Models}

A marketing model is a representation of reality regarding a marketing system or phenomena. It may be conceptualized as representation of some or all aspects of a larger marketing system of interest dealing with exchange transactions and relationships that are mutually benefitial to the relevant parties. This representation of marketing reality can be abstract, verbal or physical. According to Montgomery and Urban (1970), four major types of models used in marketing include:
a. Implicit models
b. Verbal models
c. Logical flow models, and
d. Mathematical models.

Implicit marketing models are those models which are not made explicit by some communicable form of representation. For instance, if a marketing decision maker does not put or represent his/her decisions in a communicable format, it is an implicit model since it is still residing in his/her cognitive domain. Verbal marketing models are implicit models that are put/represented in written or spoken words. Logical flow marketing models are extensions of verbal models and are represented using diagrams to depict the salient issues/features of the system being modeled. In logical flow marketing models, the diagrams are explicitly used to represent the sequence of issues/variables to be considered and how they are related. In mathematical marketing models, the relevant entities/components of the marketing system are quantified, and the magnitude and sequence of the entities/components are indicated.

Marketing models can also be classified with regard to time and risk considerations. With regard to time considerations, marketing models may be classified as static or dynamic (i.e., marketing models that do not consider time effects (static) or marketing models that consider time effects (dynamic)). With regard to risk, marketing models may be classified as stochastic and deterministic. Stochastic marketing models are those models that consider risk or probabilistic marketing phenomena of interest, while deterministic marketing models are those models that assume certainty of marketing events and outcomes.

It should be noted that marketing models may be used in triangulation or combination. For example, a marketing decision maker may use mathematical model as a part of a logical flow model which is derived from a verbal description of an implicit model. Also, it should be noted that the type of model used by a marketing decision-maker is a function of the extent of explicitness desired in the specific marketing problem or issue under consideration; the extent of explicitness, on the other hand, is a function of the benefits which the marketer hopes to get from the model with regard to his/her problem.

Marketing models are used to understand marketing problems with regard to problem identification, definition and exploration. In addition, marketing models are used to find solutions to problems. In general, marketing models are attempts to expand the marketing decision-makers' ability to understand his/her relevant marketing decision premises/environment in order to make efficient and effective marketing decisions. 
3. A Model of the Relations among Marketing Environment, Marketing Decisions and Marketing Performance Measures

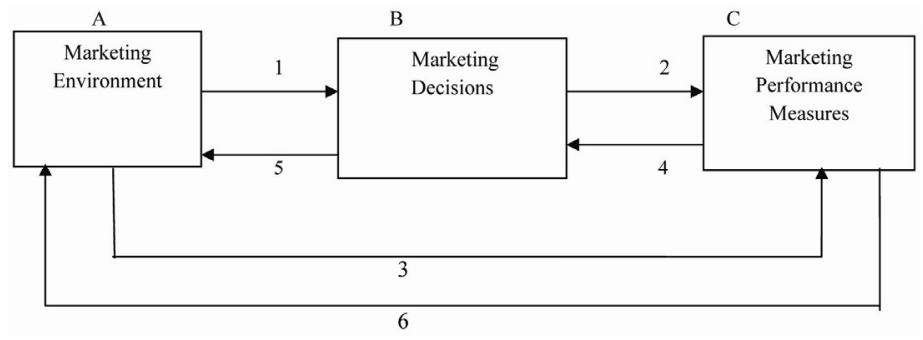

The marketing environment-decision-performance (EDP) model above shows the relationships among marketing environment, marketing decisions (strategies \& practices) and marketing performance (efficiency and effectiveness). The notations (letters and arrows) in the model show how the factors in one box influence the factors in the other boxes as shown below:

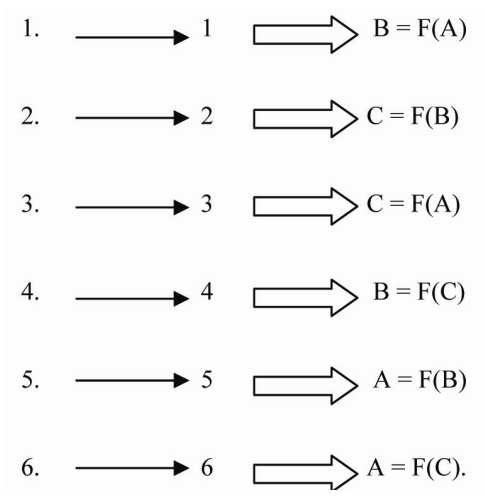

The underlying causal logic associated with the marketing EDP model is presented as:

1) marketing decisions are influenced/determined by environmental issues (see arrow 1).

2) Marketing efficiency and effectiveness (marketing performance measures) are influenced/determined by strategic marketing decisions (see arrow 2).

Therefore, for arrows 1 and 2, issues in the marketing environment will determine/influence the strategic marketing decisions of a marketer, and these marketing decisions will determine/influence the achievement (or non achievement) of marketing efficiency and effectiveness measures (marketing performance measures).

3) Marketing environmental issues can substantially determine/influence the efficiency and effectiveness (marketing performance measures) of a marketing decision (see arrow 3 ).

4) The achievement (or non-achievement) of marketing efficiency and effectiveness (marketing performance measures) can determine/influence the marketing decisions of an organization (see arrow 4).

5) Marketing decisions can determine/influence marketing environmental issues (see arrow 5).

6) Marketing efficiency and effectiveness (marketing performance measures) can substantially determine/influence issues in the marketing environment (see arrow 6).

Put differently and broadly, it is reasoned and represented/modeled that:

a) $\mathrm{A}$ can be a function of $\mathrm{B}$ and $\mathrm{C}$ (see arrows 5 and 6 ).

b) $\mathrm{B}$ can be a function of $\mathrm{A}$ and $\mathrm{C}$ (see arrows 1 and 4 ).

c) $\mathrm{C}$ can be a function of $\mathrm{A}$ and $\mathrm{B}$ (see arrows $2 \& 3$ ).

Therefore, marketing environment (A) can be influenced by strategic marketing decisions (B) and marketing performance (C). Also, strategic marketing decisions (B) can be influenced by marketing environment (A) and marketing performance measures $(\mathrm{C})$. Finally, marketing performance measures can be influenced by marketing environment (A) and strategic marketing decisions (B). This means that the marketing EDP model has reverse 
causality notations since the constructs can be conceptualized as both dependent and independent.

\subsection{Operationalization of Constructs in the Model}

Presented below is an attempt to operationalize the constructs in boxes A, B and C as contained in the model.

Box A (Marketing Environment) items can be described as the controllable or uncontrollable factors or forces that surround marketing decisions (strategies and practices). Marketers may have little or no control over the factors of the marketing environment. Below is an attempt to operationalize the factors of the marketing environment:

- Competition

- Economy

- Culture

- Technology

- Weather

- Consumer Behavior

- Laws and Regulations

- Government Policies, among others.

Box B (Marketing decisions) refers to the course of actions taken by a firm to achieve its marketing objectives while being sensitive to the environment. It should be noted that as a result of issues in the marketing environment (Box A), organizations make some relevant marketing decisions (strategies and practices). Items in Box may include:

- $\quad$ Product Policies and Strategies

- Promotional Policies and Strategies

- Pricing Policies and Strategies

- Distribution Policies and Strategies

- Megamarketing Policies and Strategies

- Market Segmentation Practices

- Demarketing Practices

- Managerial Practices in Marketing

- Relationship Management

- Other Relevant Marketing Management Decisions.

Box C (Marketing performance measures) is used to measure the efficiency and effectiveness of the marketing decisions made in box B. Listed below are some of the measures of marketing performance:

- $\quad$ Profit

- Market Share

- Sales Volume

- Cost Reduction

- Customer Satisfaction, among Others.

It should be noted that the unit of analysis for decisions in box B can be individual, organizational, or national. Therefore, what constitutes the unit of analysis in box B can alter/determine what will constitute the items in boxes $\mathrm{A}$ and $\mathrm{C}$. For example, when the unit of analysis is decision of an individual, the marketing decisions (strategies or practices) of an organization (i.e., a marketing organization) become environmental factor (i.e., box A) for such a decision of an individual. However, when the unit of analysis is an organization, the marketing decisions of the organization become box B item. Also, what is environmental factor may be different if the unit of analysis is government decisions. For example, the policies (or decisions) of government may be a function of developments in the international oil market. In this case, government policies (i.e., government decisions) constitute a box B item, while developments in the international oil market will constitute box A item. 


\section{The Model's Props and Gaps from Extant Literature}

\subsection{Props from Extant Literature}

Relevant extant literature has argued that organizational performance is a function of both controllable variables (i.e., strategic decisions or practices) and uncontrollable variables (i.e., environmental variables or premises) (Ackoff, 1970; Hansen \& Wernerfelt, 1989; Hatten, Schendel, \& Cooper, 1978; Kotha \& Nair, 1995; Lee, 2010; and Nandakumar et al., 2010, among others). This is in support of the concept of equivalence in corporate strategy which posits that effective performance of an organization is influenced by strategic choice, and the strategic choice is in turn influenced by environmental variables (Nandakumar et al., 2010; Hidayat et al., 2015).

An organizations' business environment has been conceptualized as the totality of factors and forces which have effects, or potential to have effects, on the strategies, practices and actions of the organization; these forces can be constraints, contingencies, problems and opportunities that impact on the operations and activities of the organization (Ray, 2004; Emery \& Trist, 1965).

Business organizations need to adapt to changing business environment via their strategic decisions in order to achieve their set goals and objectives. This adaptation can either be via their intelligent perceptions of the relevant environment (through information gathering) and/or through their strategic decisions or choices (Ray, 2004). Wheelen \& Hunger (2012) have advised that an organization's strategy should be designed with respect to the relevant environment in order to achieve the desired performance. Li (2014) concludes, via empirical evidence, that business environment has negative effect on organizational performance.

Generally, marketing performance measures (comprising financial and non-financial metrics) assist marketing decision-makers to understand and evaluate the implications of their strategic marketing decisions (Jaakkol et al., 2010; Varadarajan \& Jayachandran, 1999). Therefore, since strategic marketing practices affect the performance of an organization, environmental factors should be considered in this influence as they (environmental factors) moderate the influence of strategic marketing practices on performance, or directly influence marketing performance. According to Drucker (1966), achievement of strategic marketing performance is a function of an organization undertaking the right marketing practices, strategies or activities. Jaakkola et al. (2010) have argued that the impacts of strategic marketing on business performance seem elusive despite many years of research efforts, and conclude that the reason is partly traceable to the fact that the results (performance) of strategic marketing decisions are a function of many internal and external environmental factors. Short et al. (2002) argue that there is no consensus regarding the many factors that affect organizational performance. Also, it has been argued in extant literature that organizational performance is difficult to define and measure (Meyer \& Gupta, 1994; Bonoma \& Clark, 1988; Keats \& Hitt, 1988).

Strategic management literature suggests that perceived measures of performance are used in most strategic management studies because organizational management strategists tend to act on their perceptions (Dess \& Beard, 1984; Miller \& Friesen, 1984; Collier et al., 2004). According to Boyd et al. (1993), subjective or perceptual measures of organizational performance should be used when the research interest deals with getting the views of organizational members as respondents, and chief executives are perceived as the most appropriate respondents for strategic management research (Tan \& Tan, 2005; Frost et al., 2002; Bracker \& Pearson, 1986). Cronbach's alpha is a commonly used statistical technique to test data reliability when perceptual measures are used in a research (Hambrick, 1982). According to Hidayat et al. (2015), organizational performance can be measured on the bases of financial perspective, customer perspective, business process perspective and learning and commitment perspective.

Yan \& Chew (2011) developed a theoretical framework to examine the relationships among marketing strategy, business environment and performance, and found that competition (an environmental factor) is related to performance. Also, Luo (2003) and Chen (2006) submit that environmental factors determine or predict organizational performance. In addition, Hidayat et al. (2015) examined and obtained empirical evidence regarding the impacts of internal and external environments on organizational strategy and performance, and conclude that the effectiveness of an organization's business strategy is mainly a function of sensitivity to its environmental factors.

With respect to environment/performance relationship, Hambrick (1981), Venkatraman \& Prescott (1990), Hidayat \& Hairil (2009), and Tan et al. (2012), among others, have argued that environment has significant effect on organizational performance. With regard to corporate strategy and performance, relevant extant literature submits that corporate strategy has effect on organizational performance (Bracker, Keats, \& Pearson, 1988; Naffziger \& Kurato, 1991; Lyles, Baird, Orris, \& Kuratko, 1993; Osuagwu, 1996; Osuagwu, 1997; Rue \& Ibrahim, 1998; Osuagwu, 2001, Ho, 2015; and Budayan et al., 2015, among others). 
Hitt et al. (2005), among others, have argued that an organization's environments impact on its strategic decisions. Relatedly, Bamber et al. (2004) have argued that organizational strategies are a function of environmental perceptions by organizational strategists. Therefore, since organizations have different perceptions of their relevant environments, they (organizations) have different strategies (Yan \& Chew, 2011) to use in adapting to their differently perceived environments in order to achieve their marketing performance metrics. Ray (2004) developed, based on relevant extant theories, a multivariate model representing connections among environment, corporate strategy and performance and concludes, via empirical evidence, that environment has important role to play in organizational strategies and performance. Ray (2004), also, concludes that the impact of environment or organizational performance is moderated by organizational strategies.

Therefore, knowledge from extant literature seems to support part of the model, especially with regard to strategic marketing practices being a function of marketing environment (arrow 1); marketing performance being a function of strategic marketing practices (arrow 2); and marketing performance being a function marketing environment (arrow 3).

\subsection{Gap in Extant Literature}

The relationships in the marketing EDP model represented by arrows 4, 5 and 6 seem not to have been addressed in extant literature. Specifically, extant literature seems to have overlooked or ignored issues relating to influence of marketing performance on strategic marketing practices; influence of strategic marketing practices on marketing environment; and influence of marketing performance on marketing environment. Therefore, there seem to exist an empirical void in extant strategic marketing literature regarding the influence of marketing performance on strategic marketing practices; influence of strategic marketing practices on marketing environment; and influence of marketing performance on marketing environment, even though anecdotal and managerial pieces of evidence seem to support such influences.

\section{Likely Uses and Limitations of the Model}

1) The model may be useful in analyzing and understanding the reasons for strategic marketing decisions in many organizations (i.e., whether organizational marketing decisions are determined, mainly, by environmental considerations or efficiency and effectiveness considerations).

2) Marketing management scholars, among other business management scholars, may find the model useful as a basic conceptual framework in their case analysis and research works.

3) This model may assist in the development of similar models in the other organic business functions such as human resource management, financial management and operations management, among others.

Some of the limitations that may be associated with the model include:

1) The model does not depict simultaneous relationships among the three boxes (as suggested by Kotha and Nair, 1995) but rather deals with binary relationships between one construct and another. For instance, marketing environment (Box A) is represented to either influence items in strategic marketing decisions (Box B) or marketing performance (Box C); it cannot, as represented, influence the items in boxes A \& B simultaneously.

2) The variables in the model may appear to be many for a specific investigation or study, especially when the factors in each of the boxes are completely and reasonably operationalized.

3) Some researchers interested in the model may not have the necessary tools and expertise to undertake a good investigation that will test the fit of the model to empirical data.

\section{Suggestions for Future Research}

The following research suggestions are made with regard to the model:

1) Researchers are encouraged to test the fit of the model using cross sectional and longitudinal data from specific organizations, contexts, sectors and cultures regarding the relative effects of these major constructs (Mintzberg, 1978), and using relevant research techniques such as structural equation modeling, among others.

2) Researchers are also encouraged to test, via empirical data and managerial experience, the relationships in the model exhibiting the best/worst managerial relevance in specific decision premises.

3) The model may also be tested in strategic management decisions of other organic business functions (such as human resource management and financial management, among others) to determine the robustness of the model across business functions.

4) Since decision environments and performance metrics are different between personal decisions and organizational decisions, the model may be tested to understand its comparative relevance when applied in personal and/or organizational decisions. 
These suggested lines of research will likely shed more light regarding the relative relevance and robustness of the model in certain business functions, sectors, cultures, contexts or premises.

\section{Conclusion}

Strategic marketing decisions are made within a context, setting, environment or premises, and the actions and reactions of elements in the environment impact on the strategic decisions of organizations. Also, the strategic marketing decisions of organizations, in their quest to achieve organizational efficiency and effectiveness, affect the elements in the marketing context, setting, environment or premises. Therefore, these marketing factors are interrelated and should be considered in analyzing strategic marketing issues of interest to managers and researchers. This paper has attempted to sketch a simple model connecting these strategic marketing factors for consideration by decision makers and further reflection by scholars and researchers.

\section{References}

Ackoff, R. W. (1970). A concept of corporate Planning. New York: Wiley.

Anatan, L. (2006). Agile supply chain through competitive excellence. Sinergi, 8(1), 13-21.

Bamber, G. J., Lansbury, R. D., \& Wailes, N. (2004). Introduction. In G. J. Bamber, R. D. Lansbury, \& N. Wailes (Eds.), International and comparative employment relations: Globalization and the developed market economies. Sydney: Allen \& Unwin.

Bonoma, T. V., \& Clark, B. H. (1988). Marketing performance assessment. Boston, Massachusetts: Harvard Business School Press.

Boulding, W. (1994). Understanding managers' strategic decision-making process. Marketing Letters, 5(4), 413-426. http://dx.doi.org/10.1007/BF00999214

Boyd, K. B., Dess, G. G., \& Rasheed, A. M. A. (1993). Divergence between perceptual and archival measures of the environment: Causes and consequences. Academy of Management Review, 18, 204-226.

Bracker, J. S., \& Pearson, J. N. (1986). Planning and Financial Performance of Small, Mature Firms. Strategic Management Journal, 7, 503-522. http://dx.doi.org/10.1002/smj.4250070603

Bracker, J., Keats, B., \& Pearson, J. (1988). Planning and financial performance among small firms in a growth industry. Strategic Management Journal, 9(6), 591-603. http://dx.doi.org/10.1002/smj.4250090606

Budayan, C., Dimen, I., \& Birgonu, M. (2015). Alignment of project management with business strategy in construction: Evidence from the Turkish contractors. Journal of Civil Engineering and Management, 10, 94-106. http://dx.doi.org/10.3846/13923730.2013.802737

Chen, J. (2006). Development of Chinese small and medium-sized enterprises. Journal of Small Business Enterprise Development, 13(2), 140-147. http://dx.doi.org/10.1108/14626000610665854

Collier, N., Fishwick, F., \& Flloyd, S. W. (2004). Managerial involvement and perceptions of strategy process. Long Range Planning, 37, 67-83. http://dx.doi.org/10.1016/j.lrp.2003.11.012

Dess, G., \& Beard, D. (1984). Dimensions of organizational task environments. Administrative Science Quarterly, 29, 52-73. http://dx.doi.org/10.2307/2393080

Drucker, P. (1966). The effective executive. New York: Harper \& Row.

Eisend, M. (2015). Have we progressed marketing knowledge? A meta-meta-analysis of effect sizes in marketing research. Journal of Marketing, 78(3), 23-40. http://dx.doi.org/10.1509/jm.14.0288

Ellitan, L. (2006). Innovation strategy and performance manufacturing company in Indonesia: Model approach simultaneous and sequential model. Journal of Management, 6(1), 56-70.

Emery, F. E., \& Trist, E. L. (1965). The causal texture of organizational environments. Human Relations, 18(1), 21-32. http://dx.doi.org/10.1177/001872676501800103

Forman, H., \& Lancioni, R. (2002). The determinants of pricing strategies for industrial products in international markets. Journal of Business-to-Business Marketing, 9(2), 29-64. http://dx.doi.org/10.1300/J033v09n02_03

Frost, T. S., Birkinshaw, J. M., \& Ensign, P. C. (2002). Centers of excellence in multinational corporations. Strategic Management Journal, 23(11), 997-1018. http://dx.doi.org/10.1002/smj.273

Hambrick, D. C. (1981). Environment, strategy, and power within top management teams. Administrative Science Quarterly, 26, 253-276. http://dx.doi.org/10.2307/2392472

Hambrick, D. C. (1982). Environmental scanning and organizational strategy. StrategicManagement Journal, 
3(2), 159-175. http://dx.doi.org/10.1002/smj.4250030207

Hansen, G. S., \& Wernerfelt, B. (1989). Determinants of firm performance: The relative importance of economic and organizational factors. Strategic Management Journal, 10(5), 399-411. http://dx.doi.org/10.1002/smj.4250100502

Hatten, K. J., Schendel, D. E., \& Cooper, A. C. (1978). A strategic model for the U.S. brewing industry: 1952-1971. Academy of Management Journal, 21, 592-610. http://dx.doi.org/10.2307/255702

Hidayat, R., \& Hairil, B. (2009). Influence of environmental factors on strategies and performance of manufacturing industry in East Java. Semesta Journal, 12(1), 11-21.

Hidayat, R., Akhmad, S., \& Alim, M. (2015). Effects of environmental factors on corporate strategy and performance of manufacturing industries in Indonesia. Journal of Industrial Engineering and Management, 8(3), 763-782. http://dx.doi.org/10.3926/jiem.1326

Hitt, M. A., Ireland, R. D., \& Hoskisson, R. E. (2005). Strategic Management. Competitiveness and Globalization. Mason, Ohio: South Western, Thomson.

Ho, P. (2015). Analysis of competitive environments, business strategies and performance in Hong Kong's construction Industry. Journal of Management in Engineering, 10.

Jaakkola, M., Moller, K., Parvinen, P., Evanschitzky, H., \& Muhlbacher, H. (2010). Strategic marketing and business performance: A study in three European engineering countries. Industrial Marketing Management. http://dx.doi.org/10.106/j.indmarman.2010.06.005

Keats, B. W., \& Hitt, M. A. (1988). A causal model of linkages among environmental dimensions, macro organizational characteristics and performance. Academy of Management Journal, 31(3), 570-578. http://dx.doi.org/10.2307/256460

Kotha, S., \& Nair, A. (1995). Strategy and environmental determinants of performance: Evidence from Japanese machine tool industry. Strategic Management Journal, 16, 497-518. http://dx.doi.org/10.1002/smj.4250160702

Kotler, P. (1963). The use of mathematical models in marketing. Journal of Marketing, 27(4), 31-41. http://dx.doi.org/10.2307/1248643

Kumar, V. (2015). Evolution of marketing as a discipline: What has happened and what to look out for. Journal of Marketing, 79(1), 1-9. http://dx.doi.org/10.1509/jm.79.1.1

Lazer, W. (1962). The role of models in marketing. Journal of Marketing, XXVI, 9-11. http://dx.doi.org/10.2307/1248429

Lee, R. P. (2010). Extending the environment-strategy-performance framework: The roles of multinational corporation network strength, market responsiveness, and product innovation. Journal of International Marketing, 18(4), 58-73. http://dx.doi.org/10.1509/jimk.18.4.58

Li, L. (2014). Inconsistencies in international product strategies and performance of high-tech firms. Journal of International Marketing, 22(3), 94-113. http://dx.doi.org/10.1509/jim.13.0111

Longton, P. A. (1965). Mathematics, models and marketing. Human Relations, 18(3), 289-296. http://dx.doi.org/10.1177/001872676501800308

Luo, Y. D. (2003). Industrial dynamics and managerial networks in an emerging markets: The case of China. Strategic Management Journal, 24(13), 1315-1327. http://dx.doi.org/10.1002/smj.363

Lyles, M. A., Baird, I. S., Orris, J. B., \& Kuratko, F. F. (1993). Formalized planning in small business: Increasing strategic choices. Journal of Small Business Management, 31(2), 38-50.

Meyer, M. W., \& Gupta, V. (1994). The Performance Paradox. In B. M. Staw, \& L. C. Cummings (Eds.), Research in Organizational Behavior (pp.309-369). Greenwich, CT: JAI Press.

Meyer, R. T. (2015). Editorial: A field guide to publishing in an era of doubt. Journal of Marketing Research, LII, 577-579. http://dx.doi.org/10.1509/jmr.52.5.577

Miller, D., \& Friesen, P. H. (1984). A longitudinal study of the corporate lifecycle. Management Science, 30(10), 116-123. http://dx.doi.org/10.1287/mnsc.30.10.1161

Mintzberg, H. (1978). The strategy concept 1: Five Ps for strategy. California Management Review, 11-23.

Montogomery, D. B., \& Urban, G. L. (Eds.). (1970). Applications of Management Science in Marketing. New 
Jersey: Prentice-Hall.

Naffziger, D. W., \& Kuratko, D. F. (1991). An investigation into the prevalence of planning in small business. Journal of Business and Entrepreneurship, 3(2), 99-110.

Nandakumar, M. K., Ghobadian, A., \& O'Regan, N. (2010). Business-level strategy and performance: The moderating effects of environment and structure. Management Decision, 48(6), 907-939. http://dx.doi.org/10.1108/00251741011053460

Osuagwu, L. (1996). Marketing strategies, environmental variables and performance indices: A review. The Journal of Management Studies, 13, 74-100.

Osuagwu, L. (2001). An empirical evaluation of the corporate strategies of Nigerian companies. Journal of African Business, 2(2), 45-75. http://dx.doi.org/10.1300/J156v02n02_04

Osuagwu, L. C. (1997). Marketing strategies, environmental factors and performance measures in the Nigerian banking industry. Unpublished PhD thesis, School of Postgraduate Studies, University of Lagos, Nigeria.

Parakusham, R. B. (2013). A decision theoretic model for information technology. Management Studies, 1(1), 47-63.

Ray, S. (2004). Environment-strategy-performance linkages: A study of Indian firms during economic liberalization. VIKALPA, 29(2), 9-23.

Rue, L. W., \& Ibrahim, N. A. (1998). The relationship between planning sophistication and performance in small businesses. Journal of Small Business Management, 36(4), 24-32.

Short, J. C., Ketchen, D. J., \& Palmer, T. B. (2002). The role of sampling in strategic management research on performance: A two-study analysis. Journal of Management, 28(3), 363-385. http://dx.doi.org/10.1177/014920630202800306

Simon, H. A. (1997). Administrative behavior: A study of administrative processes in organizations (4th ed.). New York: The Free Press.

Tan, J., \& Tan, D. (2005). Environment-strategy co-evolution and Co-alignment: A staged model of Chinese SOEs under transition. Strategic Management Journal, 26(2), 141-157. http://dx.doi.org/10.1002/smj.437

Tan, Y., Shen, L., \& Langston, C. (2012). Competition environment, strategy and performance in the Hong Kong construction industry. Journal of Construction and Engineering Management, 138(3), 352-360. http://dx.doi.org/10.1061/(ASCE)CO.1943-7862.0000407

Varadarajan, P. R., \& Jayachandran, S. (1999). Marketing strategy: An assessment of the state of the field and outlook. Journal of the Academy of Marketing Science, 27(2), 120-143. http://dx.doi.org/10.1177/0092070399272002

Venkatraman, N., \& Ramunajam, V. (1987). Measurement of business economic performance: An examination

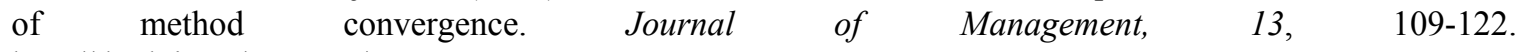
http://dx.doi.org/10.1177/014920638701300109

Wheelen, T. L., \& Hunger, J. D. (2012). Strategic Management and Business Policy: Toward Global Sustainability (13th ed.). Boston: Pearson Education, Inc.

Yan, S., \& Chew, D. A. S. (2011). An investigation of marketing strategy, business environment and performance of construction SMEs in China. African Journal of Business Management, 5(6), 2396-2405.

\section{Copyrights}

Copyright for this article is retained by the author(s), with first publication rights granted to the journal.

This is an open-access article distributed under the terms and conditions of the Creative Commons Attribution license (http://creativecommons.org/licenses/by/3.0/). 